\section{The Teaching of Biology}

My colleague Prof. D. G. Catcheside has not, I think, had much experience either of teaching elementary biology or of devising syllabuses. If he had, he would know that his proposals ${ }^{1}$ for unifying the teaching of biology, at present consisting largely of long words that are meaningless until they are defined, will have to be translated into lecture notes, text-books and examination questions. When this has been done he will find, I suspect, that, allowing for natural evolution, what is presented to the student will be much the same as has been given to him for a good long time. My own school education in physics and chemistry, for example, now more than thirty years old, included almost everything in his list, the only omissions being things such as high-energy bonds which were not then known. It included also the method of dimensions, surface tension, sound, general wave theory, and other topies that are not in his list, but which are just as necessary to the zoologist as any that are.

The premises of Catcheside's arguments appear to be two, both of which are unproved.

(1). "The reality of biology as a subject lies in the unity inherent in the apparently universal similarity in the constitution of cells." I am not going to enter into the interesting questions whether biology is real or ideal and whether non-cellular organisms ought so easily to be excluded from its scope, but what is important is that for me and for many others the interest of biology lies in its diversity. To say that because sperm tails and ferm cilia have a similar structure there is a "lack of serious distinetion between plant and animal material" is ludicrous; Prof. Catcheside is not an oak tree nor am I a nettle, and to pretend that we are is nonsense. The "universal similarity" (which every schoolboy knows to be extremely limited) makes the diversity more, not less, remarkable.

(2). That there is such a thing as "the whole deductive and inferential structure of biology as a science". On the contrary, biology is mainly inductive, and many of Catcheside's topies are standing on their heads both historically and philosophically. Thus, if you study "the structure and functions of genes and the problems of development and differentiation" you are likely to go nowhere except into a blind alley, but you may fruitfully study development and then try to see what part the genes, so far as they are known, may play in it. If Catcheside's second premise were true The Origin of Species would never have been written.

The tragedy of this sort of attempt to eliminate organisms from biology and to make it into a sub-division of physics lies in its possible educational effect. The world is full of physical scientists who never have to make judgments and of administrators whose living is making judgments with no science. The biologist stands in between. He must know enough physics to be able to deduce from given facts within the framework of Nature's laws, but in many fields - ocology, taxonomy, palæontology-he has to exercise his judgment on inadequate facts with few or no laws to guide him. For this reason he can be an important bridge between science and government. This, in both the short and the long run, is a more important task for many biologists than finding out more about nucleic acid.

Department of Zoology and

W. B. YAPP

Comparative Anatomy,

University of Birmingham.

${ }^{1}$ Catcheside, D. G., Nature, 197, 427 (1963).

I AM delighted that Mr. Yapp's letter should be published, to show what obstacles must be overcome by reformers of biological teaching. His letter shows how badly reform is needed.

\section{Department of Microbiology, University of Birmingham.}

\section{SOIL SCIENCE}

\section{Biotite - Hydrobiotite - Vermiculite in Soils}

IN the course of experiments dealing with the potassium chemistry of a group of alluvial and colluvial soils of California decived largely from weathering products of granite-diorite, we have observed the occurrence of minerals, presumably alteration products of biotite, which include trioctahedral vermiculite ${ }^{1}$ and hydrobiotite $\Theta^{2,3}$ (regularly interstratified biotite-vermiculite). The minerals occur in some abundance in the fine sand, silt, and $0.5-2 \mu$ clay and are responsible for from $20-50$ per cent of the cation-exchange capacity of the soils examined. A typical X-ray diffraction pattern for a magnesium-silt fraction, showing $25-\AA$ and $12 \cdot 5$ - $\AA$ peaks from hydrobiotite, 14.48 and $7 \cdot 24 \AA$ diffraction maxima from vermiculite and a $10 \cdot 1-\AA$ mica line is reproduced in Fig. $1 A$. Only $10 \cdot 1-\AA$ and $7 \cdot 1-\AA$ pesks were observed after saturation with potassium and air-drying, while sodium saturation resulted in peaks at $22 \cdot 5,12 \cdot 3,11 \cdot 25$, and $10 \cdot 1 \AA$. Treatment of magnesium material with glycerol or ethylene glycol did not change peak positions.

To establish whether the micaceous minerals existed as separate flakes or intergrowths, the 100-200 mesh fraction of a Hanford soil (0-12-in. layer) was subjected first to magnetic and then specific gravity separation. For the latter, magnetic minerals were saturated with magnesium and placed consecutively in mixtures of tetrabromoethane and toluene which differed in density by 0.05 unit between $2 \cdot 35$ and 2.95 . The density separation was attempted on the grounds that 14 Â magnesiumvermiculite should have a density 0.82 that of biotite, with hydrobiotite midway between. The relatively unaltered biotite had a density near $2 \cdot 95$, leading to expected values for vermiculite and hydrobiotite of $2 \cdot 42$ and $2 \cdot 68$, respectively.

Yields were largest in the density-ranges $2 \cdot 40-2 \cdot 45$, $2 \cdot 55-2 \cdot 60,2 \cdot 65-2 \cdot 70$, and above $2 \cdot 80$ (Table 1 ), suggesting that the sample may have been separated into four mineral species. X-ray diffraction patterns obtained using a North American Phillips instrument, utilizing copper $K \alpha$-radiation with $1^{\circ}$ slits and a scanning period of $1^{\circ} 2 \theta$ per min, showed the supposition to be largely correct. Traces of the diffraction patterns between $2^{\circ}$ and $14^{\circ} 2 \theta$ for the main fractions (Fig. $1 B-F^{*}$ ) show the presence of vermiculite with only a trace of hydrobiotite in the material less dense than $2.45(B)$, hydrobiotite with some vermiculite at density between 2.55 and $2.60(C)$, almost pure hydrobiotite of density $2 \cdot 65-2 \cdot 70(D)$, and slightly altered biotite $(F)$ of density $2 \cdot 85-2 \cdot 95$. Pattern $E$ in Fig. 1 was given by material with density $2 \cdot 70-2 \cdot 75$, regarded as intergrown biotite-hydrobiotite. The sharp $7 \cdot 1-\AA$ peaks in $D$ and $E$ are due largely to chlorite.

The fractions of different density were examined microscopically and cation-exchange capacities determined by leaching with ${ }^{86} \mathrm{RbCl}$ followed by water washing and direct counting of the rubidium- 86 photo peaks.

The refractive index (Table 1 ) decreased from $>1.695$ for biotite to about 1.605 for magnesium-vermiculite. Hydrobiotite frections had refractive indices between $1 \cdot 640$ and $1 \cdot 660$. Potassium-saturation of vermiculite raised the refractive index to about $1 \cdot 655$, above that for hydrobiotite but well below the value for biotite.

The mica flakes of density $>2.95$ showed no distortion, gave good interference figures, and exhibited sharp extinction. Distorted edges and fuzzy interference figures were observed in the $d=2 \cdot 85-2.95$ fraction, and distortion increased progressively in the lighter fractions. The material with densities between 2.50 and 2.65 consisted mainly of puffed or accordion-like grains, while the vermiculite $(d<2.45)$ was in the form of thin distorted plates. The microscopic appearance along with the rather gradual change in refractive index with decrease 